Pak. j. sci. ind. res. Ser. A: phys. sci. 2018 61A(1) 43-50

\title{
Monthly Monitoring of Physicochemical and Radiation Properties of Kufa River, Iraq
}

\author{
Sadiq Kadhum Lafta Alzurfi, Ali Abid Abojassim* and Hussien Abid Ali Mraity \\ Faculty of Science, University of Kufa, Al-Najaf Box 21, Najaf, Iraq
}

(received September 8, 2017; revised December 14, 2017; accepted January 19, 2018)

\begin{abstract}
Increasing anthropogenic activities can lead to a dramatic effect on the quality of the planet surface water such as river, lake and wetland among others (i.e. groundwater and atmospheric water). Water samples were collected from Kufa river during six months (i.e. started from November, 2015 to April, 2016). Six stations were selected alongside the river flow. The samples were analysed for physicochemical and radiation properties (air temperature, water temperature, $\mathrm{pH}$, total hardness, $\mathrm{Ca}^{+2}, \mathrm{Mg}^{+2}$, total dissolved solids, dissolved oxygen, biological oxygen demand, turbidity, total alkalinity, electrical conductivity and radon concentration). The resulted data of various physicochemical parameters indicate that in some water samples, the EC, total hardness, BOD, turbidity, and total dissolved solids were found to be high when compared with the limits of WHO standards. Regarding the radon concentration, the results reveal that the radon level of all studied areas were lower than those published in literature. Finally, the findings the river's water could be unsafe for drinking when the physicochemical analysis taken into account.
\end{abstract}

Keyword: physicochemical properties, radon concentrations, Kufa river

\section{Introduction}

Kufa river extends from Al-Kifl city via Al-Najaf governorate to Al- Diwaniyah city; the total length of this river is around $36 \mathrm{~km}$ long with an approximate flow rate of $552 \mathrm{~m}^{3} / \mathrm{sec}$. The water level in this river undergoes large fluctuations. To illustrate, the highest level occurs during the high rainy season (end of March to early of April), whereas the lowest water level occurs in summer (MWR, 2007). Increasing urbanization of Kufa city had negative implications on water quality where the domestic effluents are directly disposed into the river without any consideration for the environmental consequences. Nevertheless, transported radioactive matters (e.g. radon gas) should also be considered as they may have their own impact too. Radon is a colourless, odourless and radioactive noble gas that is resulted from uranium decay series, which exists elsewhere on the earth. Furthermore, radon is an alpha particle emitter that decays into a chain of progenies of gamma and alpha emitters. This means that the radon atoms in the air can decay and produce other new atoms. The resulting atoms called radon progeny. These atoms can attach themselves to a tiny dust particle in an indoor air. As a result, the dust particles could easily be entered into the respiratory system and increase the chance of developing lung cancer over long period of time. In this

*Author for correspondence;

E-mail: ali.alhameedawi@uokufa.edu.iq context, certain types of radon based lung cancer have been recognized in literature especially those caused by smoking (BEIR, 1999). Overall, the US Environmental Protection Agency (USEPA, 1991) has identified pollutants relying on quality standards as follows:

- The concentration of chemical compounds and elements, i.e organic, chlorine, nitrates, ammonia, phosphorus, sulphates, and others.

- Pollutants that have an effect on the physical and chemical properties such as temperature, alkalinity conductivity, $\mathrm{pH}, \mathrm{DO}$, hardness and TDS.

- Biological contaminants include pathogenic bacteria, viruses, protozoa, helminthes, and phytoplankton.

- Radionuclides also includes natural radioactive families such as ${ }^{238} \mathrm{U}$ and ${ }^{232} \mathrm{Th}$ and their decay chain includes the production of radon-222;220; 219 progenies. The latter are all emitting alpha particles. Some other radioactive elements emit beta and gamma rays.

It should be noted that the destination of industrial pollutants when entering the water surface either remain unchanged and immobile in primary station or move via transportation, volatilization, leaching, adsorption, and sedimentation processes. Finally, it might also move under the influence of gravity and diffusion where in some cases transmitted via biological and chemical 
processes (e.g. aerobic and anaerobic decomposition) and bioaccumulation via some weathering processes (Weiner, 2000).

This study is aimed to monitor the physical, chemical and radiation properties of the six stations along side of the Kufa river's water using different techniques and comparing the findings with published standards for water. These stations were identified as sampling sites using a geographical positioning system (GPS)

Study area. Euphrates river in the Kifl city is divided into two branches namely, Abbasid and Kufa rivers. It runs from the Kifl city to the Diwaniyah city with a total length of about 36 kilometers and a flow rate of $375\left[\mathrm{~m}^{3} / \mathrm{s}\right]$, and an actual capacity of $552\left[\mathrm{~m}^{3} / \mathrm{s}\right]$. The depth of water in this river changes and has a marked high level during the flooding seasons at the end of March to beginning of April and has a low water level in the summer's months (Al-Haidarey, 2009).

Many villages, farm lands and cities (e.g.Najaf and Kufa) lie alongside the river, where the waste of human and industrial fluid (industrial district area, Kufa cement plants and leather factory and others), together with rainy water and hospitals waste drain into the river directly without treatment.

The geographical positionging system (GPS) use in (Fig. 1) as follows:

- First station (St.1): Located north of Imam Ali Bridge about $1 \mathrm{~km}$; this characterized by there was no industrial activity or human except agricultural activities.

- Second station (St.2): Located near Al-Barrakhia treatment plant for domestic wastes of the Kufa city.

- Third station (St. 3): located at $1 \mathrm{~km}$ away from the second station.

- Fourth station (St. 4): Located at $1.3 \mathrm{~km}$ away from the third station.

- Fifth station (St. 5): Located at $1.7 \mathrm{~km}$ away from the fourth station under the cement plant bridge.

- Sixth station (St. 6): Located $3 \mathrm{~km}$ away from the fifth station.

\section{Materials and Methods}

Samples of water were collected during day from the selected stations of Kufa river for the period starting from November, 2015 to April, 2016. Six stations were chosen for monitoring the physical, chemical and radiation properties of water in Kufa river. Analysis of the samples was achieved in the laboratory of Ecology Department/Faculty of Science/Kufa University. The samples were collected from a depth of $20 \mathrm{~cm}$ in each station (using polyethylene container). Air and water temperature was measured using mercury thermometer $\left(0-100^{\circ} \mathrm{C}, \mathrm{UK}\right)$, while the electrical conductivity, TDS, salinity, and $\mathrm{pH}$ were measured using multi meter (WTW, Germany). A modified method of Winkler (APHA,1995) was adapted to determine DO after fixing in field, the turbidity was measured using portable Turbid meter (Lovibond, Germany) after calibration of the meter using different solutions $(0.01,10,1000)$. Total alkalinity was measured according to Lind (1979), whereas, total hardness, $\mathrm{Ca}^{+2}$ and magnesium hardness were measured according to APHA (1995). Radon concentration $\left(\mathrm{Bq} / \mathrm{m}^{3}\right)$ was measured using RAD-7 detector. The RAD-7 is a radon-in-air monitor containing an inside vacuum pump associated with an alpha semiconductor detector that employs energy discrimination to count the daughters of radon 222 and thoron (radon-220). This tool has widely been used in the recent water studies; (Abojassim et al., 2017; AlHamidawi, 2015). The RAD-7 can be considered as an absolutely machine controlled and moveable element detector, capable of running endlessly for days. An important demand of this method is that the air stream provided to the unit remains dry (humidity $<10 \%$ ).

Statistical analysis. Two-way ANOVA test was used for further statistical analyses together with correlation analysis. The value $\mathrm{P}<0.05$ was considered statistically significant. All statistics were performed using Microsoft Excel 2007.

\section{Results and Discussion}

The study area is known to be affected by the local weather of middle part of Iraq which is variable from cold in winter to dry hot in summer; this associated with a moderate temperature during spring and autumn. Figure 2 illustrates monthly variations of air temperature in the research area. The highest values of the temperature were recorded in April at the sixth stations $\left(34^{\circ} \mathrm{C}\right)$, while the lowest value was seen in January at the first station $\left(10.4^{\circ} \mathrm{C}\right)$. Figure 3 shows the monthly variations of water temperature in the studied area. The highest value was recorded in April at the sixth station $\left(28.5^{\circ} \mathrm{C}\right)$ and the lowest value in January was seen at the first station $\left(9.8{ }^{\circ} \mathrm{C}\right)$. The temperature during the present study was recorded at measurement time and does not represent the variation during the whole day. 


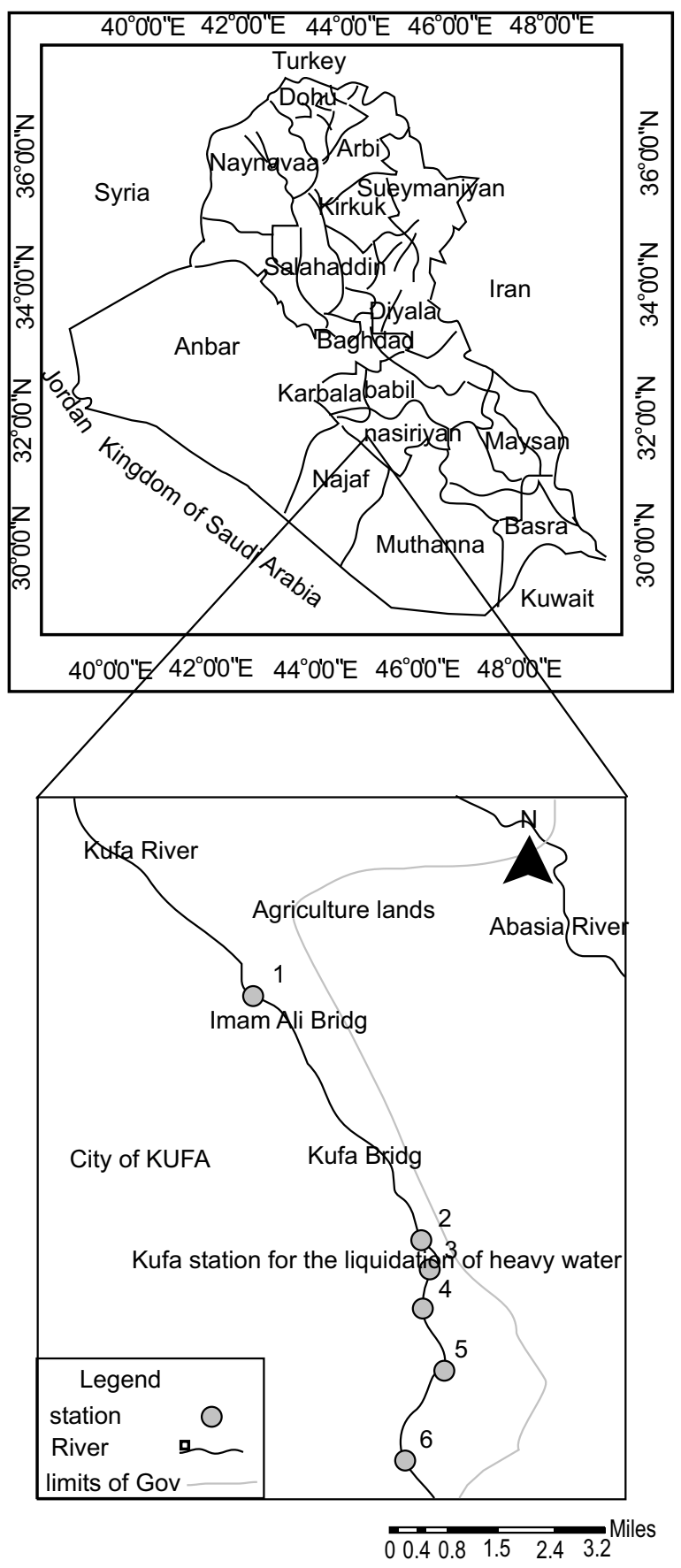

Fig. 1. Base map of the study stations.

Air and water temperature were clearly variable in relation to the weather conditions during measurement time.

The monthly variations of $\mathrm{pH}$ were found to be between 5 and 8.5 for stations 1 and 2 during November and February, respectively. The $\mathrm{pH}$ findings demonstrate a narrow range in the selected stations due to its high

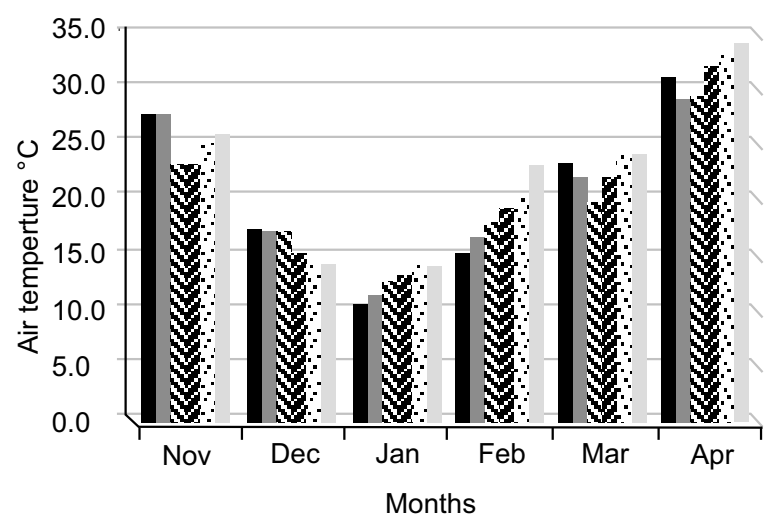

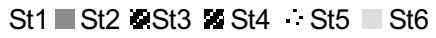

Fig. 2. Monthly variations of air temperature (mean) in study stations.

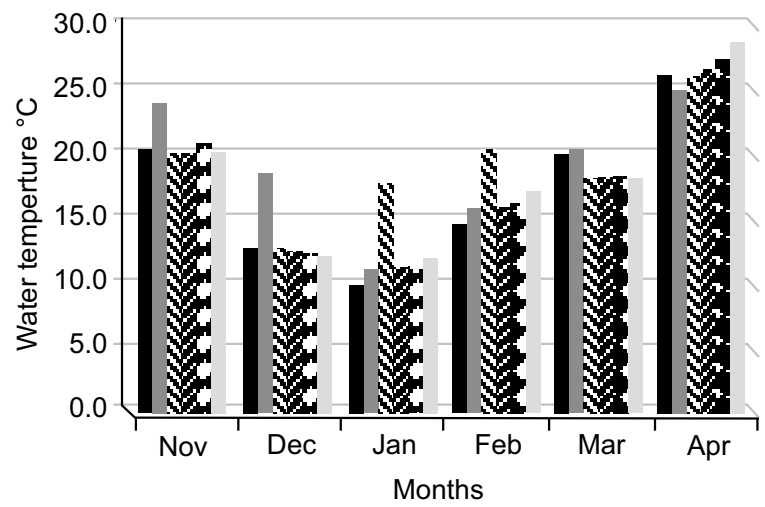

- St1 $\square$ St2 $\mathrm{NSt} 3 \approx \mathrm{St} 4 \quad \therefore \mathrm{St5} \backsim \mathrm{St} 6$

Fig. 3. Monthly variations of water temperature (mean) in study station.

ability to be regulated in hardness water and rich alkalinity with bicarbonates (i.e. buffer system) (Goldman and Horne,1983) and showed in Fig. 4. The value of $\mathrm{pH}$ decreased in station 2 during November due to the drainage of the domestic wastes from Barrakhia treatment plant across the river that contains a large amount of wastes which would be expected to affect the $\mathrm{pH}$ levels. High proportions of electrical conductivity, salinity and total dissolved solid values were recorded in station 2 as $(2963 \mu \mathrm{s} / \mathrm{cm}, 1.9$ ppt. and $1491 \mathrm{mg} / \mathrm{L}$ ), respectively during February in Fig. 5-7. The electrical conductivity is an important factor through which estimation of the total salts in water can be obtained (Table 1). Water in station 1 was fresh but in station 2 was brackish which would indicate that the domestic wastes have a marked impact in increasing 


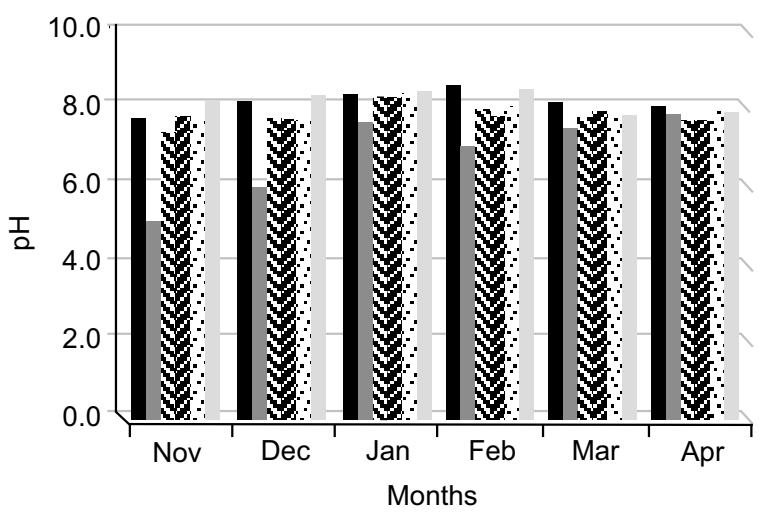

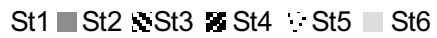

Fig. 4. Monthly variations of $\mathrm{pH}$ (mean) in study station.

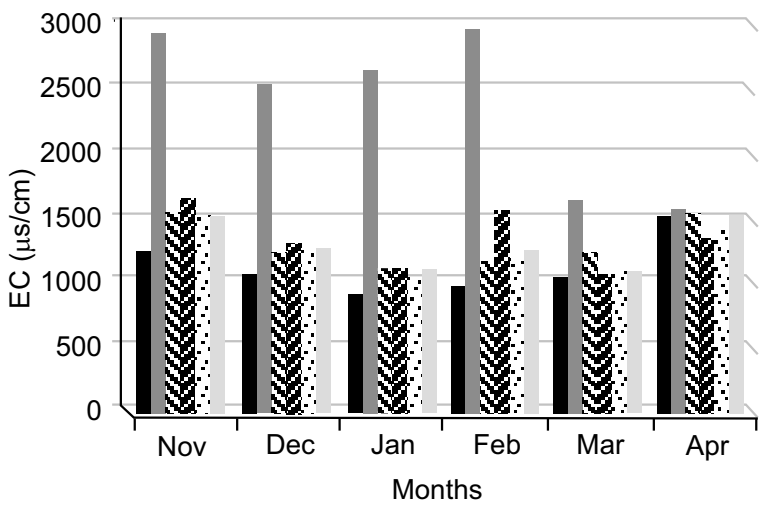

St1 $\square$ St2 $\quad$ St3 $\boldsymbol{a}$ St4 $\quad \therefore$ St5 $\square$ St6

Fig. 5. Monthly variations of electrical conductivity (mean) in study station.

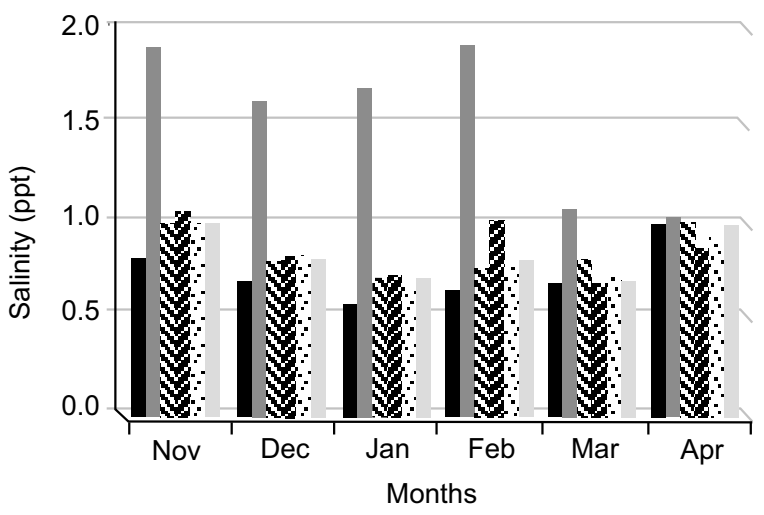

Fig. 6. Monthly variations of salinity (ppt) (mean) in study station.

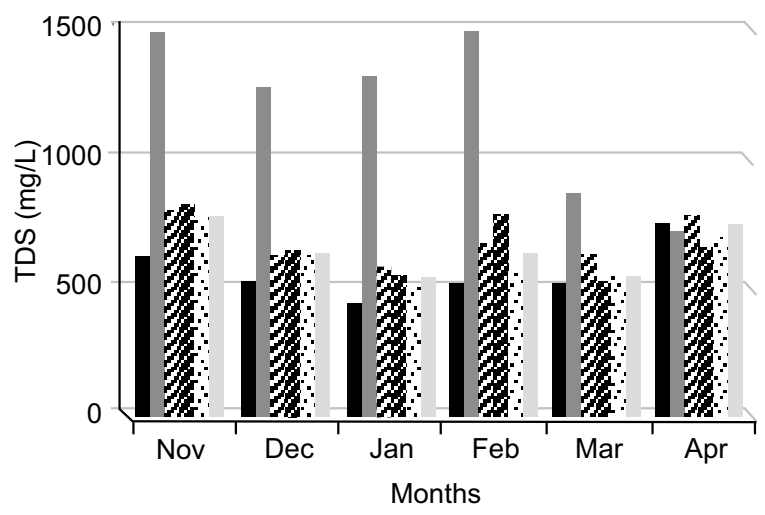

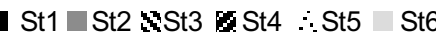

Fig. 7. Monthly variations of total dissolved solid (mean) in study station.

the electrical conductivity, salinity and total dissolved solid values of the river (Al-Zurfi et al., 2010). Figure 8 demonstrates the monthly recorded variations of turbidity where a high rate can be seen in station 2 ; this can be attributed to the amount of drainage of domestic wastes plant to the river and the growth of high numbers of microorganisms which has a positive relation to the turbidity. In this regard, Wetzel (2001) referred to the DO in water that has essential role in the metabolic processes of all aquatic organisms. The oxygen is added to water from atmosphere or due to photosynthesis processes of phytoplankton and aquatic plants (Wetzel and Linkens, 2000). It is well known that the DO is a limiting factor to the growth of much of aquatic organisms (Douabul et al., 2013). Variation in the levels of the DO can be attributed to the variation in temperature

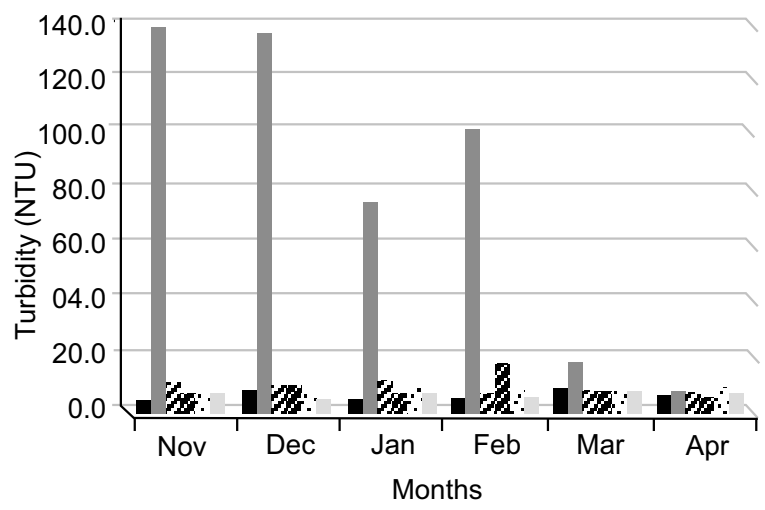

St1 $\mathrm{St} 2 \mathbf{z S t} 3 \mathbf{z S t} \quad \therefore \mathrm{St} 5 \square \mathrm{St} 6$

Fig. 8. Monthly variations of turbidity (mean) in study station. 
(Haward, 1998), pressure and different ions concentration in water (Wetzel and Linkens, 2000). This study reveals that there is a clear depletion in the DO values at station 2 which is below the detection limit (DL) during November (Fig. 9), this is owing to the decrease in water level and decay processes of organic material which may be caused by the drainage of domestic wastes in this station (Al-Saadi et al., 1999). However, DO increase in other stations during February could be attributed to good aeration, continuous mixing, high water level and decrease of temperature during this month (Hassan, 2004) as seen in Table 1. The biological oxygen demand $\left(\mathrm{BOD}_{5}\right)$ refers to consumptive amount of oxygen of the added organic material to water that are destroyed by microorganisms. This has a negative effect on the quality of water (Wiener, 2000). The results demonstrate that the rise in the BOD values in station 2 during March was $6 \mathrm{mg} / \mathrm{L}$ than in (Fig.10) which is exceeding the acceptable international limit of $5 \mathrm{mg} / \mathrm{L}$ (WHO, 1996). This can be attributed to the direct addition of domestic wastes from Barkyia plant to the river. This finding agrees with (Al-Zurfi et al., 2010; Al-Mousawi et al.,1995). The recorded BOD values in the present study was found to be high compared with results of the Euphrates river at Simawah city (Mushkor, 2002) and lower than the values obtained by Salman (2006) in Euphrates river at Hindhia city. Total hardness values were found in the range between (160 and 1347) $\mathrm{mg} / \mathrm{L}$ in station 6 and 2 during March and December in Fig.11, respectively. The results demonstrate that the total hardness during the study period was higher than the total alkalinity concentration which may be attributed to the amount of $\mathrm{Ca}^{+2}$ and $\mathrm{Mg}^{+2}$ ions that affected the

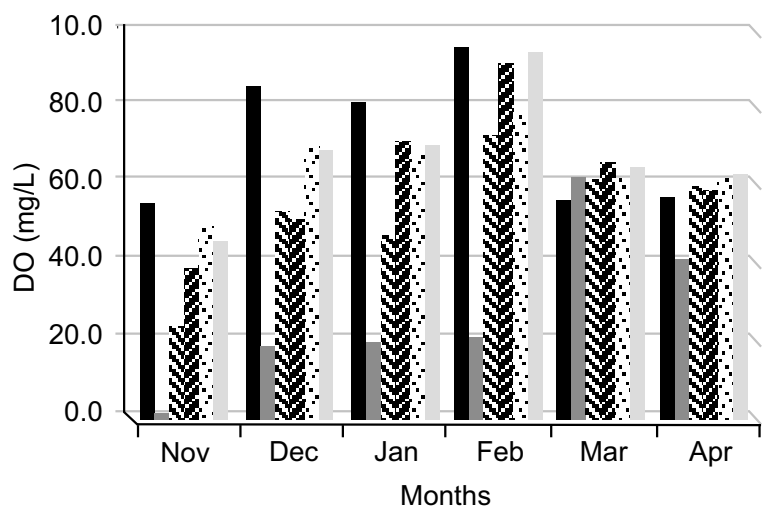

- St1 St2 $\approx$ St3 $\approx$ St4 $\because$ St5 $\square$ St6

Fig. 9. Monthly variations of DO (mean) in study station. total hardness (Lind, 1979), where the rise in the $\mathrm{Ca}^{+2}$, $\mathrm{Mg}^{+2}$ ions and bicarbonates in the north area of Iraq is owing to the soil nature, rise of sodium, chloride, sulphates and carbonate ions compared with the south. This change is concurrent with groundwater nature that has a level in medium and southern areas (Al-Lami et al., 1999; Talling, 1980). The findings of this study are well agreed with many previous studies that were concerned with rise of total hardness in Iraqi water (AlZurfi et al., 2010; Salman, 2006).

This study mostly shows that the $\mathrm{Ca}^{+2}$ concentration is higher than that of $\mathrm{Mg}^{+2}$ as in Fig. 12. This is because the reaction of $\mathrm{CO}_{2}$ with $\mathrm{Ca}^{+2}$ is higher and stronger than the reaction with $\mathrm{Mg}^{+2}$ ions, and large amount of $\mathrm{Ca}^{+2}$ is converted into dissolve bicarbonates, which

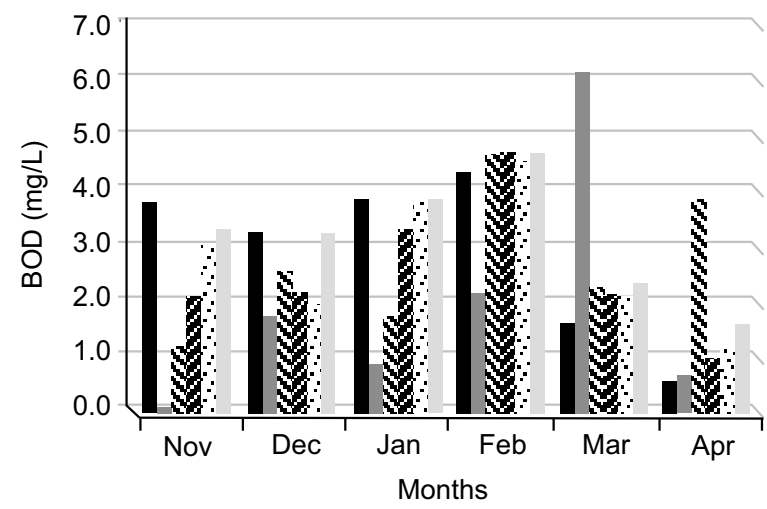

$\square \mathrm{St} 1 \square \mathrm{St} 2 \mathrm{st3} \approx \mathrm{St} 4 \quad \therefore \mathrm{St} 5 \square \mathrm{St} 6$

Fig. 10. Monthly variations of biological oxygen demand (mean) in study station.

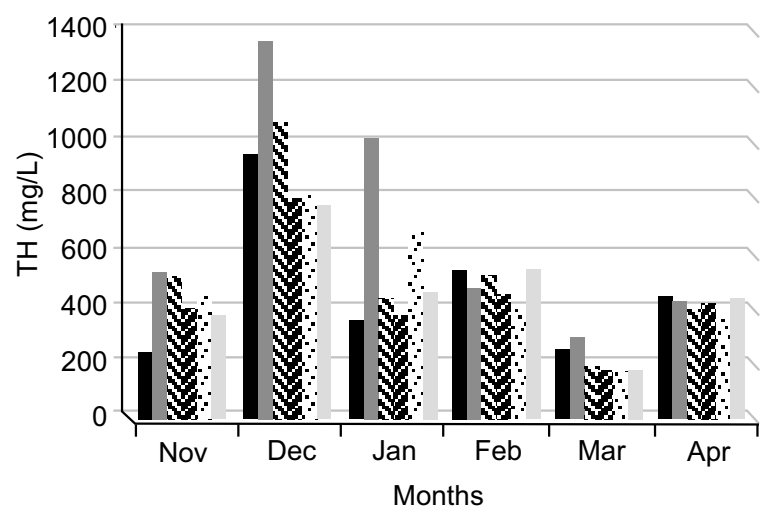

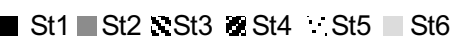

Fig. 11. Monthly variations of total hardness (mean) in study station. 


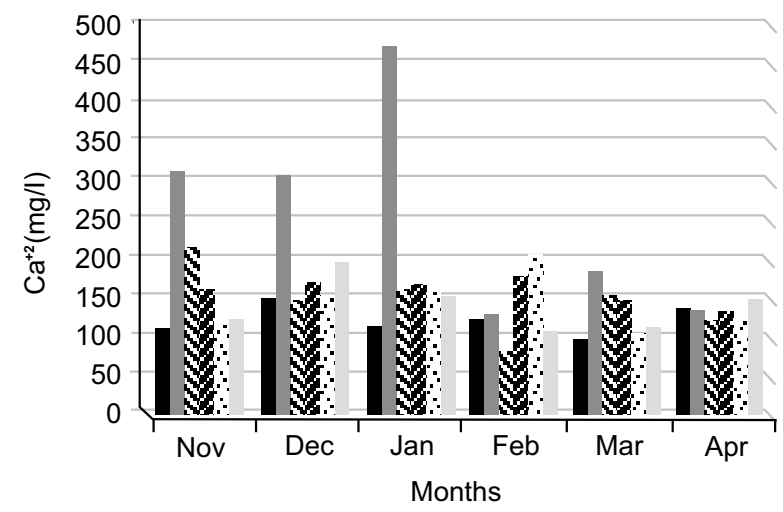

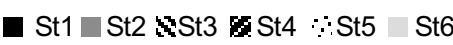

Fig. 12. Monthly variations of $\mathrm{Ca}^{+2}$ hardness (mean) in study station.

affects on the hardness level as reported by Kassim (1986). The high concentration of $\mathrm{Ca}^{+2}$ shows in some stations of $\mathrm{Mg}^{+2}$ ions in Fig. 13. This is due to driftage processes from adjacent soil or flowage caused by the domestic and industrial wastes (Al-Lami et al.,1999) or may be due to the presence of huge numbers of phytoplankton (Maulood and Al-Mousawi, 1989). In the present study, no carbonate is reported, whereas the hydroxide alkalinity of the river is high due to high bicarbonates which was high in station 2 during November at $323 \mathrm{mg} / \mathrm{L}$ and low in station 1 during February at $99 \mathrm{mg} / \mathrm{L}$ as showed in Fig. 14.

The high value of alkalinity of the river can be attributed to the rise of temperature and increasing decay rates of organic material which would increase the conversion

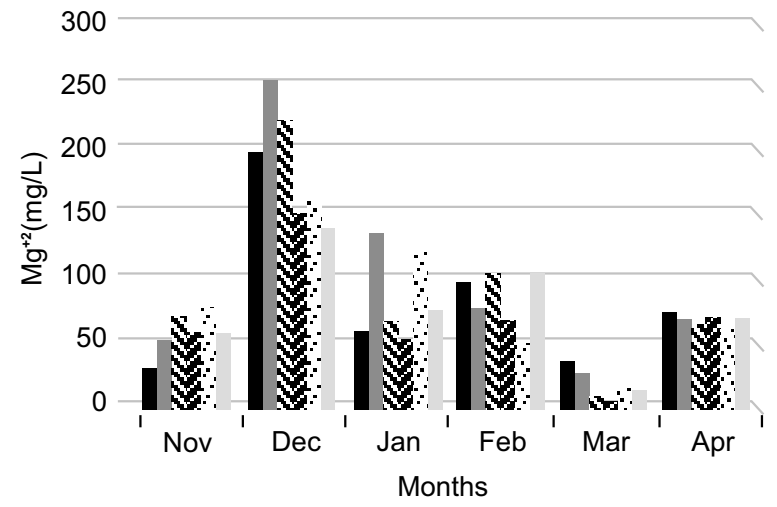

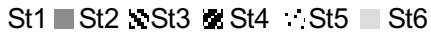

Fig. 13. Monthly variations of $\mathrm{Mg}^{+2}$ hardness (mean) in study station.

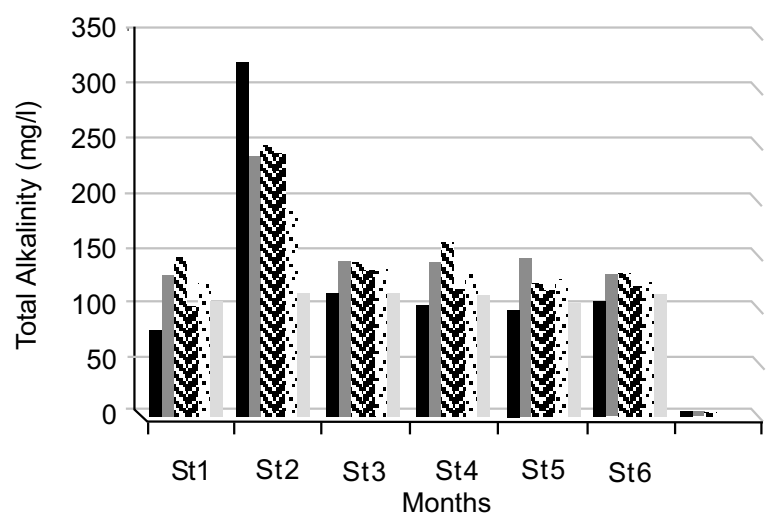

Nov Dec $\approx$ Jeb $\because$ Mar $\square$ Apr

Fig. 14. Monthly variations mean of total alkalinity in study station.

of insolvent $\mathrm{Ca}^{+2}$ carbonate to bicarbonate (Hassan et al., 2004). The expectant rate of total alkalinity in natural water is ranged from 20 to $200 \mathrm{mg} / \mathrm{L}$ (APHA, 1985). It was observed in the present study that the results are within this range and slightly higher; similar findings were also observed with the bicarbonates alkalinity level. The latter findings were agreed with that of previous studies when alkalinity in Iraqi water was taken into account which could be explained by presence of bicarbonate salts in water and adjacent soil recorded (Al-Lami et al., 1999; Al-Saadi et al.,1996; Maulood et al.,1994; Sabri et al., 1989; Al-Nimma,1982). In term of radon investigation, a positive correlation was found between the $\mathrm{Ca}^{+2}, \mathrm{Mg}^{+2}$ and radon concentrations at 0.88 and 0.67 , respectively as showed in Fig. 15. The investigation also revealed that the maximum radon

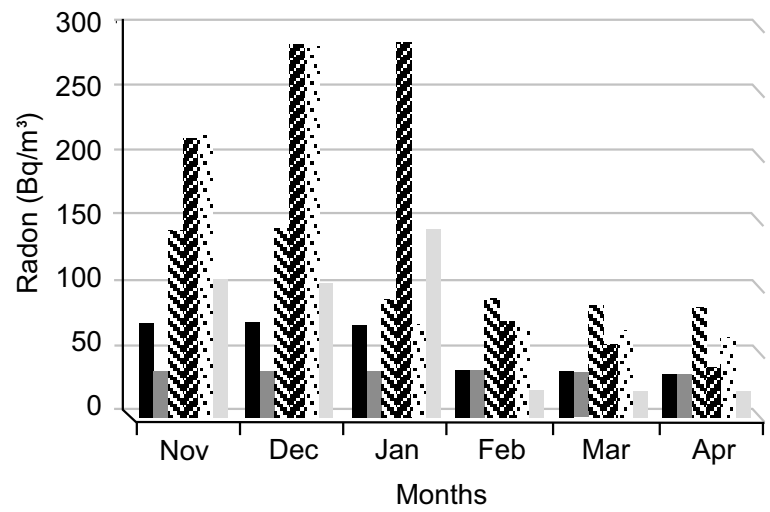

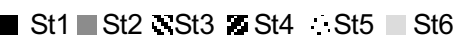

Fig. 15. Monthly variations of radon (mean) in study station. 
Table 1. Correlation beteen physical and radiation properties during study period.

\begin{tabular}{lllllllllllllll}
\hline \hline & W.temp & A.temp. & $\mathrm{pH}$ & $\mathrm{EC}$ & Salinity & $\mathrm{TDS}$ & Turbidity & $\mathrm{DO}$ & $\mathrm{BOD}$ & $\mathrm{T} . \mathrm{H}$ & $\mathrm{Ca}^{+2}$ & $\mathrm{Mg}^{+2}$ & T. Alk. & Radon \\
\hline W.temp & 1.00 & 0.99 & -0.37 & 0.34 & 0.34 & 0.28 & -0.53 & -0.3 & -0.59 & -0.46 & -0.69 & -0.49 & -0.97 & -0.56 \\
A.temp. & 0.99 & 1.00 & -0.46 & 0.36 & 0.36 & 0.30 & -0.49 & -0.36 & -0.61 & -0.53 & -0.68 & -0.47 & -0.94 & -0.50 \\
pH & -0.37 & -0.46 & 1.00 & -0.68 & -0.68 & -0.67 & -0.45 & 0.73 & 0.41 & -0.01 & 0.03 & -0.11 & 0.19 & -0.40 \\
EC & 0.34 & 0.36 & -0.68 & 1.00 & 1.00 & 0.99 & 0.57 & -0.54 & -0.14 & 0.16 & 0.06 & 0.16 & -0.27 & 0.31 \\
Salinity & 0.34 & 0.36 & -0.68 & 1.00 & 1.00 & 0.99 & 0.57 & -0.54 & -0.14 & 0.16 & 0.06 & 0.16 & -0.27 & 0.34 \\
DO & -0.30 & -0.36 & 0.73 & -0.54 & -0.54 & -0.50 & -0.27 & 100 & 0.66 & 0.04 & -0.36 & 0.09 & 0.07 & -0.52 \\
BOD & -0.59 & -0.61 & 0.42 & -0.14 & -0.14 & -0.04 & 0.34 & 0.66 & 1.00 & 0.01 & -0.04 & 0.02 & 0.45 & -0.13 \\
T.H & -0.46 & -0.53 & -0.01 & 0.16 & 0.16 & 0.15 & 0.63 & 0.04 & 0.01 & 1.00 & 0.62 & 0.99 & 0.53 & 0.73 \\
Ca & -069 & -0.68 & 0.03 & 0.06 & 0.06 & 0.07 & 0.58 & -0.36 & -0.04 & 0.62 & 1.00 & 0.53 & 0.78 & 0.88 \\
Mg & -0.49 & -0.47 & -0.11 & 0.16 & 0.16 & 0.15 & 0.60 & 0.09 & 0.02 & 0.99 & 0.53 & 1.00 & 0.46 & 0.67 \\
T.Alk. & -0.97 & -0.94 & 0.19 & -0.27 & -0.27 & -0.20 & 0.60 & 0.07 & 0.45 & 0.53 & 0.78 & 0.46 & 1.00 & 0.69 \\
Radon & -0.56 & -0.50 & 0.40 & 0.31 & 0.31 & 0.32 & 0.79 & -0.52 & -0.13 & 0.73 & 0.88 & 0.67 & 0.69 & 1.00 \\
\hline \hline
\end{tabular}

$\mathrm{W}$. temp= water temperature; A.temp= Air temperature; T. Alk= Total alkaline; $\mathrm{T} . \mathrm{H}=$ Total hydroxide alkalinity

concentration was in December, 2015 at station 4 was $284 \mathrm{~Bq} / \mathrm{m}^{3}$ which is within acceptable limit as indicated by WHO (1996).

\section{Conclusion}

In the present study the analytical data of various physicochemical properties indicate that some parameters such as EC, hardness, BOD, turbidity, and total dissolved solids found to be higher than the prescribed limit in some water samples as compared to WHO (1996). The Barrakhia treatment plant affected the water quality of the river during wastes drainage that sometimes occurs directly without treatment and this is incompetent with waste treatment process. However, the radon concentration in water can be considered as safe therefore no doubt can be raised due to radon.

\section{References}

Abojassim, A.A., Kadhim, S.H., Mraity, H.A.A., Munim, R.R. 2017. Radon levels in different types of bottled drinking water and carbonated drinks in Iraqi markets. Water Science and Technology Water: Supply, 17: 206-211.

Al-Hamidawi, A.A.A. 2015. Monitoring of ${ }^{220} \mathrm{Rn}$ concentrations in buildings of Kufa Technical Institute, Iraq. Science and Technology of Nuclear Installations, 2015: 1-5.

Al-Haidarey, M.J. 2009. Diurnal Variation of Heavy Metals in Al-Kufa River/Najaf, Iraq, $10^{\text {th }}$ Conference of Biogeochemistry of Trace Element, July, Maxico.

Al-Lami,A.A., Kassim, T.I., AL-Dylymei, A.A. 1999. A limnological study on Tigris river, Iraq. The Scientific Journal of Iraqi Atomic Energy Commission, 9: 59-66.

Al-Mussawi, A.H.A., Hussien, N.A., Al-Aarajy 1995. The influence of sewage discharge on the physico- chemical properties of some ecosystem at Basrah city, Iraq. Basrah Journal of Agriclture Science, 13: $135-148$.

Al-Nimma, B.A.B. 1982. A Study on the Limnology of the Tigris and Euphrates Rivers, M.Sc. Thesis Salahaddin University, Erbil, Iraq, 72pp.

Al-Saadi, H.A., Al-Edany, T.Y., Neama, J.D. 1999.On the distribution and ecology of aquatic plants in the Shatt Al-Arab river, Iraq. Marina. Mesopotamica, 11: 49-62.

Al-Saadi, H.A., Al-Lami, A.A., Kassim, T.I., Al-Jaberi, H.H. 1996. Heavy metals in Qadisia lake and its aquatic plants. Journal of the College of Education For Women, 10: 281-292.

Al-Zurfi, S.K., Mohammed, A.K., Shaheed, A.I. 2010. Study of some physical and chemical of Kufa River. Journal of Babylon University/Pure and Applied Sciences, 18: 1399-1411.

APHA, 1995. Standard Methods for the Examination for Water and Wastewater. $19^{\text {th }}$ edition. American Public Health Association, Byrd Prepress Springfield, Washington, USA

APHA, 1985. Standard Methods for the Examination of Water and Wastewater. 1268pp, $16^{\text {th }}$ edition. American Public Health Association, Washington, D.C. USA.

BEIR, 1999, Biological Effect On Ionizing Radiation Report VI, Health Effects of Exposure to Radon, pp 516, The National Academics Press, Washington, USA.

Douabul, A.A.Z., Al-SAAD, H.T., Abdullah, D.S., Salman, N.A. 2013. Designated protected Marsh within Mesopotamia: water quality. American Journal of Water Resources, 1: 39-44.

Goldman, C.R., Horne, A.J. 1983. Limnology, 464pp, McGraw Hill, New Yark, USA. 
Hassan, F.M. 2004. Limnological features of Diwaniyah river, Iraq. Baghdad Science Journal, 1: 119-124.

Howard, A.G. 1998. Aquatic Environment Chemistry. 96pp. Oxford Science Publications, November, UK.

Kassim, T.A. 1986. Environmental Study on Benthic Algae of Some Marsh Regions in Southern of Basra. MSc. Thesis. University of Basra, Iraq.

Lind, G.T. 1979. Handbook of Common Methods in Limnology, $2^{\text {nd }}$ edition., 199pp., London, UK

Maulood, B.K., Al-Azzawi, M.N.A., Saadalla, A.A. 1994. An ecology study of the Tigris river pre and after crossing Baghdad. Journal of College of Education for Women, 5: 43-50

Maulood, B.K., Al-Mousawi, A.H. 1989. Limnological investigation on Sawa lake, Iraq. Basrah Journal of Agriculture Sciences, 21: 113-122.

Mushkor,S.K. 2002. Sewage wastewater and industrial effect for Smwia city in Euphrates river pollution. Journal of Al-Qadisiyah for Pure Sciences, 7: 2940. (Arabic)

MWR, 2007. General Properties of Al-Kufa River, Ministry of Water Resources / Najaf Annual Report, June 2007.

Sabri, A.W., Maulood, B.K., Sulaiman, N.E. 1989. Limnological studies on river Tigris: Some physical and chemical characters. Journal of Biological Sciences, Research, 20: 565-579.
Salman, J.M. 2006. Environmental Study of Potential Pollution in Euphrates River Between Hindyhia Dam and Kufa City, Iraq. PhD Thesis, Babylon University. 192 pp.

Talling, J.F. 1980. Phytoplankton. In: Euphrates and Tigris, Mnnogr. Biol. J., Rzoska, and W Junnk (eds.) Junk, W. 122 pp., The Hague-Boston, London, UK.

USEPA, 1991. Methods for aquatic toxicity identification evaluations: Phase I, toxicity characterization procedures. T. Norberg-King, D.I. Mount, E. Durhan, G. Ankley, L. Burkhard, J. Amato, M. Lukasewycz, M. Schubauer Berigan, and L. Anderson-Carnahan (eds). Environmental Research Laboratory, U.S. Environmental Protection Agency, Duluth, Minnesota, $2^{\text {nd }}$ edition, USA.

Weiner, E.R. 2000. Application of Environmental Chemistry. 276 pp. Lewis Publisers, London, New York, USA.

Wetzel, R. G. 2001. Limnology, Lake and River Ecosystems, $3^{\text {rd }}$ edition, 1006pp. Academic Press, An Elsevier Science, Imprint,

Wetzel, R.G., Linkens, G.E. 2000. Limnological Analysis. $3^{\text {rd }}$ edition, pp. 429. Springer Science: Business Media.

WHO 1996. Guideline for Drinking Water Quality, $2^{\text {nd }}$ eddition, 94pp., World Health Organization, Switzerland. 